\title{
Statyba
}

\section{TECHNOLOGICAL MODEL OF BUILDING LIFE CYCLE}

\section{Martinaitis \& A. Rogoža}

To cite this article: V. Martinaitis \& A. Rogoža (2001) TECHNOLOGICAL MODEL OF BUILDING LIFE CYCLE, Statyba, 7:1, 73-77, DOI: 10.1080/13921525.2001.10531702

To link to this article: https://doi.org/10.1080/13921525.2001.10531702

册 Published online: 30 Jul 2012.

Submit your article to this journal

Џ Article views: 124

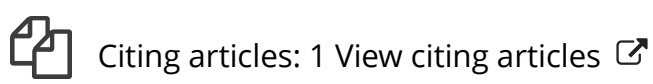




\section{STATINIO GYVAVIMO CIKLO TECHNOLOGINIS MODELIS}

\section{Martinaitis, A. Rogoža \\ Vilniaus Gedimino technikos universitetas}

\section{Ivadas}

Šiuo metu Lietuvoje nèra privalomų dokumentu, reglamentuojančiụ statinio gyvavimo norminę trukmę, statinio gyvavimui privalomų priežiūros, remonto, rekonstrukcijos darbų normini turini ir dažnị. Vertinant pastato tikslinę renovacija, ypač energijos taupymui skirtus jos sprendimus, nèra atsižvelgiama i statinio vertès (fizinès ar ekonominćs) padidejimą. Praktika parodè, jog tokių elementų, kaip vietinio šilumos punkto modernizavimas, šildymo sistemos renovacija ir subalansavimas yra ekonomiškai efektyvios energijos taupymo priemonès. Tačiau langụ keitimas, stogo renovacija, sienụ apšiltinimas ir panašaus pobūdžio darbai dẻl palyginti dideliụ investicijụ ekonomiškai paprastai nèra efektyvūs (paprastas lèšų sugrị̌imo laikas viršija 10 metų), nors šiu priemonių itraukimas i pastatų renovaciją taip pat padeda taupyti šilumą. Taip yra dèl to, kad šiuo atveju pastato konstrukcijų renovacijos nauda nagrinejjama tik kaip išlaidų šilumai sumažejjimas. Tačiau akivaizdu, kad tokių priemonių igyvendinimas yra ir pastato konstrukcijų elementų būklès atkūrimas, ir viso pastato ilgaamžiškumo prailginimas. Be to, pastato dalių ir elementu renovacija leidžia išvengti šių elementų būklès palaikymo darbụ išlaidų bei investicijų ateityje, kurios, visiškai nusidèvejjus pastato daliai ar elementui, būtų neišvengiamos. Tokia padètis neleidžia formaliai pagrịsti (pvz., ieškant investicijų, kreditų) didesnès statinio renovacijos, kurioje lygiagrečiai būtų atliekamos kelios tikslinès (fizinès, energinès, architektūrinès ir pan. būklès pagerinimo) renovacijos. Ekonominiam šių procesų pagrindimui reikia statinio ilgaamžiškumo pokyčius vertinančio per visą statinio gyvavimo laiką technologinio modelio.

Iki šiol nèra būdų, kuriais galima būtų ịvertinti, kokią itaką statinio ilgaamžiškumui turi tam tikrų statinio dalių ar jo elementų atnaujinimas ar pakeitimai.
Dėl šios priežasties buvo sukurtas modelis, kuriuo remiantis gali būti planuojami statinio atnaujinimo darbai ir ivertinta atskirų darbu itaka jo tolesnei eksploatacijai. Be to, toks modelis išplèstų kitų fiziniụ (energetinių, termodinaminių) modelių $[1,2]$ analitines galimybes.

\section{Metodas ir modelio parengimas}

\subsection{Statinio gyvavimo ciklo technologinio modelio paskirtis}

Vertinant statinio dalies ar elemento renovacijos itaką statinio ilgaamžiškumui, svarbiu rodikliu laikoma statinio likutinè vertè. Atvirkščias likutinei vertei dydis yra statinio nusidévejimas. Statinio gyvavimo ciklo technologinio modelio paskirtis yra ivertinti statinio likutinę vertę bet kuriuo laiko momentu procentais nuo naujo statinio pirminès vertès. Pagal [3] fizinis statinio dalies ar elemento nusidevejimas yra jo pirminiu techninių ir eksploatacinių savybių (stiprumo, patvarumo, patikimumo ir kt.) praradimas dè gamtinių, klimatiniu veiksnių ir žmogaus veiklos.

Modelio išeities duomenys yra informacija apie statinio struktūrą, viso jo ir atskirų struktūrinių jo dalių jrengimo, paskutinio keitimo ar atnaujinimo laiką, gyvavimo ir efektyvaus naudojimo minimalias trukmes.

\subsection{Statinio dalys ir elementai}

Nagrinėdami statini kaip objektą, turime apžvelgti jo struktūrą. Todèl statinys yra skirstomas i žemesnio lygio (pagal savo struktūrą) dalis. Taigi turime tris lygmenis ( 1 pav.), kuriuos sąlygiškai pavadinsime taip: statinys, statinio dalis ir elementas (statini sudaro statinio dalys, o statinio dalis - elementai).

Esant sudètingesnei objekto struktūrai, skirstymas gali būti detalesnis, pvz., elementai skirstomi i subelementus ir pan. 


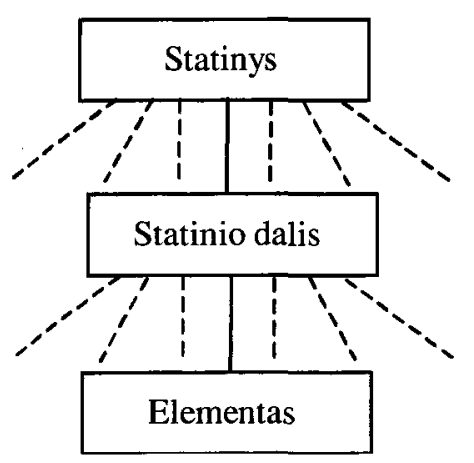

1 pav. Statinio struktūrinè schema

Fig 1. Building structural scheme

\subsection{Svorio koeficientai}

Visos statinio dalys bei dalių elementai nèra vienodi pagal jụ svarbą statiniui keliamų reikalavimų atžvilgiu ir pagal jụ funkcinę paskirti. Ši svarba gali būti kelių rūšių, tačiau nagrinèjama svarba pagal struktūrinès dalies pradinę vertę viso statinio pradinès vertès atžvilgiu.

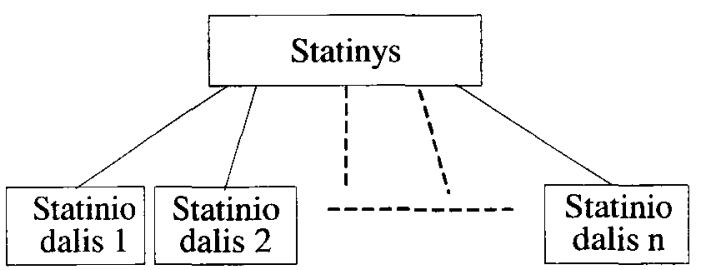

$$
S D_{1}+S D_{2}+\ldots+S D_{n}=1
$$

2 pav. Svorio koeficientu paskirstymo schema

Fig 2. Distribution scheme of weighting coefficients

Svorio koeficientais vieneto dalimis (procentais) ivertinama statinio dalies svarba visam statiniui arba elemento svarba statinio daliai ( 2 pav.), pvz., statinio dalių svorių suma lygi vienetui (arba šimtui procentų).

Statinio dalies svorio koeficientas pagal pradinę kainą rodo jo kainos santyki su visų vieno statinio daliu kaina.

\subsection{Gyvavimo trukmè ir efektyvaus naudojimo minimali trukmé}

Tolesnis žingsnis yra nustatyti struktūrinių dalių gyvavimo trukmę. Ji išreiškiama pastoviu skaičiumi (metais), kuris yra normuojamas kiekvienai statinio daliai ir kiekvienam elementui. Tačiau reikia skirti dvi kiekvienos struktūrinès dalies trukmes - gyvavimo trukme ir efektyvaus naudojimo minimalia trukmę. Kai kurioms statinio dalims ar elementams šios trukmès yra lygios, tačiau yra ir tokių dalių, kurių nurodyta efektyvaus naudojimo minimali trukmè yra trumpesnè už gyvavimo trukmę. Šias struktūrines dalis keisti arba remontuoti reikia nesulaukus jụ gyvavimo trukmès pabaigos, o, to nepadarius, tolesnè jų eksploatacija gali sukelti pavoju žmogaus gyvybei ar viso pastato tolesniam gyvavimui.

Nagrinejjant statini, kurio kai kurios dalys ir/ar elementai jau buvo rekonstruoti ar remontuoti, reikètu ivertinti, ar statinio dalis ar elementas atstatytas iki visos pradinès vertès, ar iki tam tikros jos dalies. Todèl $\mathrm{i}$ technologini modeli itraukiamas rekonstrukcijos arba remonto laipsnis, kuris nurodo, kokią pradinès vertès dali pasiekè statinio dalis ar elementas po rekonstrukcijos ar remonto.

\subsection{Nusidèvèjimo dèsningumas}

Nusidèvejjimo kitimo pobūdi galima rasti tik pasinaudojus gausiais statistiniais stebejjimų duomenimis. $\mathrm{S}_{\mathfrak{i}}$ pobūdi galima išreikšti matematine funkcija. Kitas būdas - tiriamo statinio dalies ar elemento būklès vizualus ịvertinimas. Tačiau šiuo atveju neišvengiama didelio subjektyvumo, atsakymas randamas tik tam tikram laiko momentui. Remiantis [3, 4] pateiktų fizinio nusidèvèjimo kitimo kreivių pobūdžiu, siūloma taikyti funkciją:

$$
P=\frac{1}{b}\left[a-\ln \left(\frac{U \times R L+c}{T+d}-1\right)\right]
$$

$P$ - statinio dalies arba elemento nusidèvejjimas, \%; $U$ - statinio dalies arba elemento gyvavimo trukmé; $T$ - esama statinio dalies ar elemento naudojimo trukmé; $R L$ - atnaujinimo (remonto) lygis, vieneto dalimis; $a, b$ - funkcijos ribojimų koeficientai, $c, d-$ funkcijos proporcingumo koeficientai. Šie koeficientai lemia nusidèvèjimo kreivès simetriškuma, t. y., kai jų santykis $d / c=0,5$, kreivè yra simetriška. Šiuos dydžius galima keisti ir parinkti tinkamas ju reikšmes nagrinèjamai statinio daliai/elementui.

\subsection{Likutinè vertè}

Atvirkščias nusidévejjimui dydis yra statinio dalies arba elemento likutinè vertè:

$$
V=R L \times 100-P \text {. }
$$




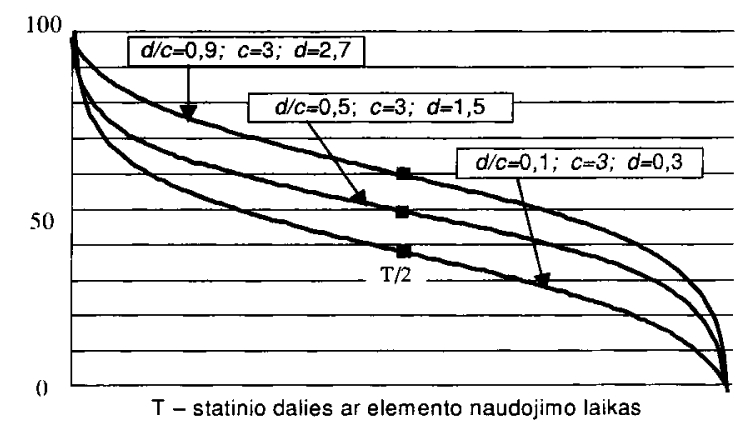

3 pav. Statinio dalies ar elemento likutinès vertès pasiskirstymas per visa jo gyvavimo laiką

Fig 3. Building construction (element) depreciable values function throughout its life cycle

3 paveiksle matome likutinès vertès pasiskirstymo kreivių variantus, esant skirtingoms $d$ ir $c$ reikšmèms. Tašku ant kreiviụ yra pažymèta pusė gyvavimo trukmés. Esant simetriškam pasiskirstymui $(\mathrm{d} / \mathrm{c}=0,5)$, pusè gyvavimo trukmés atitinka pusę pradinès likutinés vertès. Didejant $\mathrm{d} / \mathrm{c}$ santykiui, dideja ir pusés gyvavimo trukmes likutinè vertè. Tokios funkcijos (lygties) naudojimas leidžia, kaupiant statistinius ar mokslinių tyrimụ duomenis apie nusidèvèjimo kitimo pobūdị bei parinkus $d$ ir $c$ reikšmes, patikslinti kreivès pobūdị. Iki šiol likutinè vertès sąvoka buvo taikoma tik statinio dalims arba elementams, kuriu gyvavimo trukmé yra žinoma.

Tačiau, norèdami nustatyti statinio dalies arba viso statinio likutinę vertę, negalime taikyti minètos matematinès išraiškos, kadangi neturime jụ gyvavimo trukmès. Todèl kitas žingsnis - nustatyti sudètingos statinio dalies ar viso statinio likutinę vertę (arba nusidèvèjimą).

Kadangi turime kiekvienos konstrukcinès dalies nustatytus svorio koeficientus, galime apskaičiuoti statinio dalies arba viso statinio likutinę vertę:

$$
V_{E}=V_{1} \times S D_{1}+V_{2} \times S D_{2}+\ldots+V_{n} \times S D_{n},
$$

$V_{E}$ - statinio dalies (ar viso statinio) likutinè vertè, $\% ; V_{n}-$ n-tojo elemento (ar statinio dalies) likutiné vertè, \%; $S D_{n}-$ n-tojo elemento (ar statinio dalies) svorio koeficientas vieneto dalimis.

Pasirinkdami ilgiausios gyvavimo trukmès elementą (arba statinio dali), prilyginame skaičiuojamajị laiko intervalą elemento (arba statinio dalies) gyvavimo trukmei. Tada apskaičiuojame statinio dalies (arba viso statinio) likutines vertes kiekvienais to intervalo metais.
Laikydami, kad, pasibaigus elementu (arba statinio daliu) gyvavimo trukmei, jie nebus keičiami ar atnaujinami, gauname statinio dalies (arba viso statinio) likutinès vertès pasiskirstymo grafini modelị nuo jo gyvavimo pradžios iki visiško susidèvéjimo. Toks sprendimas grafiškai pavaizduotas 4 paveiksle, kur statinio dalies vaidmuo tenka stogui (ištisinè linija), o elementụ - jo konstrukcinèms dalims (danga, gegninè santvara, latakai, lietaus nuleidimo vamzdžiai ir stovai).

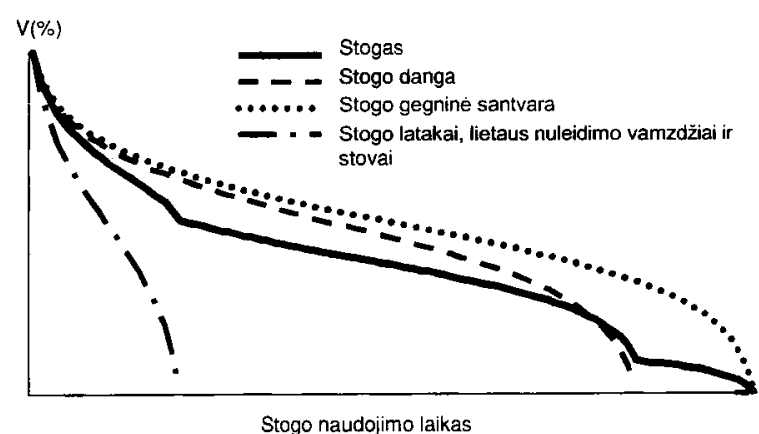

4 pav. Stogo likutinès vertès pasiskirstymo funkcijos pavyzdys

Fig 4. Example of roof depreciable value function

Tačiau kiekvienam elementui (arba statinio daliai) yra nustatyta jo gyvavimo trukmé arba efektyvaus naudojimo minimali trukmé, kuriai pasibaigus jis turi būti pakeistas arba atnaujintas. Dèl šios priežasties grafinis likutinès vertès modelis atrodys kitaip, t. y. elementai (arba statinio dalys) bus keičiami ar atnaujinami, pasibaigus ju gyvavimo ar efektyvaus naudojimo minimaliai trukmei, o elemento (arba statinio dalies) naudojimas formaliai niekada nesibaigs, t. y. statinys niekada nebus nugriautas.

Būtent toki atveji matome 5 paveiksle. Elementụ kreivès taip pat nepasiekia nulinès likutinès vertes, kadangi laikoma, kad jụ visiško nusidèvejjimo metais jie bus pakeisti naujais arba atnaujinti.

Statinio likutinè vertè galètụ bũti laikoma svarbiu rodikliu, ivertinant statinio būklę bei tam tikrụ ateities rekonstrukcijų itaką statinio tolesnei eksploatacijai.

\section{Rezultatai}

Taikant sukurtą modelị buvo atliktas likutinés vertẻs skaičiavimas menamam pastatui, kurio pradiniai duomenys imti atsižvelgiant $\mathfrak{i}$ realias sąlygas. 6 paveiksle pateiktas šio skaičiavimo grafinis pavyzdys. Iš jo 


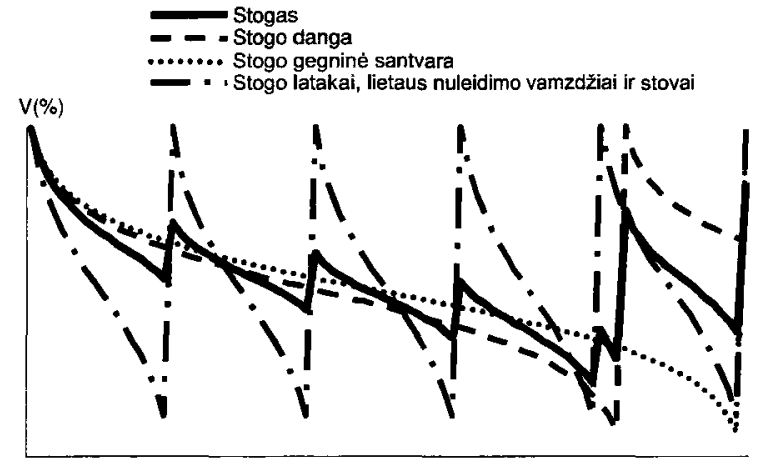

Stogo naudojimo laikas

5 pav. Stogo pasiskirstymo funkcija, atstatant jo konstrukcines dalis

Fig 5. Distribution function of roof depreciable value in case, when components are reconditioned

matome, kaip viso pastato likutinès vertès kitimas (storesné kreive) priklauso nuo pastato elementu, kurie yra išvardyti dešinèje paveikslo pusejje, likutinių verčiu kitimo. Staigus pastato likutinès vertès šuolis rodo stambiụ elementų, ypač svarbiu pagal savo svori (pvz., karkasas), atnaujinimo darbụ vienalaikiškumą. Panašaus pobūdžio šuolis galètu ìvykti ir dèl smulkių elementụ atnaujinimo darbų vienalaikiškumo, tik šiuo atveju elementų skaičius turètų būti didesnis.

\section{Išvados}

1. Taikant autoriy sukurta statinio gyvavimo ciklo technologini modeli galima nustatyti sudètingo statinio (pastato, inžinerinès sistemos) likutinès vertès reikšmę ateičiai, bet kuriam laiko momentui.

2. Kadangi Lietuvoje nèra privalomų dokumentu, reglamentuojančiu statinio gyvavimo norminę trukmę bei atnaujinimo darbụ dažni, taikant ši modelị galima būtu ieškoti optimaliụ jų reikšmių bei jas reglamentuoti remiantis skaičiavimo rezultatais.

3. Taikant modeli galima nustatyti statinio likutinès vertès reikšmės priklausomybę nuo atskiru jo elementụ atnaujinimo ar keitimo pobūdžio, t. y. galima nagrinèti statinio fizinę vertę ateityje, taikant kelis atskirų elementu atnaujinimo ar keitimo variantus.

4. Atsirandant naujoms technologijoms, elementu keitimo ar atnaujinimo metu, gali keistis tolesnis tu elementụ nusidèvejimo kreivès pobūdis. Ji galima kontroliuoti modelyje keičiant koeficientus.

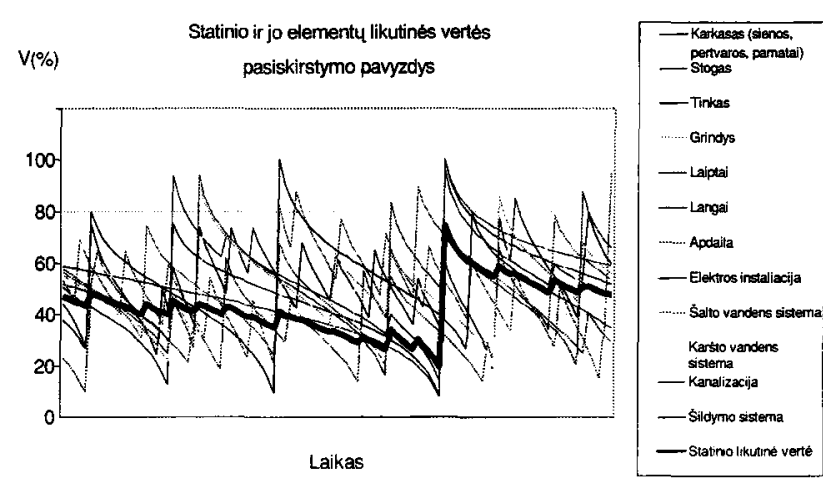

6 pav. Pastato ir jo elementul likutinè vertè

Fig 6. Depreciable value of building and its elements

5. Atskiru elementu pakeitimas ar atnaujinimas turi itakos ne tik statinio estetiniam vaizdui, ilgaamžiškumui, bet ir eksploatacinèms išlaidoms (energijos sąnaudoms, priežiūros darbụ apimčiai), kurios galètụ būti siejamos su tam tikrụ elementụ nusidèvèjimu.

6. Šis modelis yra pavadintas technologiniu, todèl i jị neieina išlaidụ darbams, medžiagoms ir energijai nustatymas, tačiau juo remiantis galima toliau modeliuoti ekonomini statinio gyvavimo ciklą.

\section{Literatūra}

1. V. Martinaitis. Thermodynamical analysis model of building life cycle. Summary of the research report presented for habilitation. Vilnius: Technika, 2000. 64 p.

2. K. Čiuprinskas. Vienbučio namo energijos sąnaudụ modeliavimas ir šilumos izoliacijos paskirstymo optimizavimas. Daktaro disertacijos santrauka. Vilnius: Technika, 1999. $36 \mathrm{p}$.

3. Правила оценки физического износа жилых зданий. ВСН 53-86(р) / Госгражданстрой. Москва, 1988. 71 с.

4. Hohlstein, D. Wolff. Finanzierung Profit für alle Performance Contracting - die Überzeugendste Form des Contractings // Sanitär und Heizungstechnik. Düsseldorf, 1999, Nr. 9, S. 50-55.

Iteikta $2000 \quad 1107$

\section{TECHNOLOGICAL MODEL OF BUILDING LIFE CYCLE}

\section{Martinaitis, A. Rogoža}

\section{Summary}

Under present conditions there are no regulating documents for building life span, maintenance, recondition and reconstruction works and periodicity in Lithuania. The suggested model allows to evaluate optimal values for building work periodicity. 
The purpose of the model is to calculate the depreciable value of compound construction (building) at every moment of its life cycle.

There can be determined by this model the relations between building depreciable value and its components reconstruction character.

The function mode of components deterioration can be changed with technology progress. It can be controlled by single coefficients in model.

Single components reconstruction affects not only building aesthetic conditions, but also operating costs (energy consumption, amount of renovation work), which could be linked with elements deterioration.

This model is called technological model, and it does not include cash expenditure calculations for work, materials and energy, but it is a basis for further economical modelling of building life cycle.

Vytautas MARTINAITIS. Doctor Habil, Professor. Dept of Heating and Ventilation. Vilnius Gediminas Technical University, Saulètekio al. 11, LT-2040 Vilnius, Lithuania. E-mail: vm@eksergija.stp.lt
Doctor (1982, power engineering and heat engineering). Since 1972 at Kaunas Polytechnical Institute, in 1986-89 in Algeria (Constantin University), since 1989 at Vilnius Technical University. Research courses: Belorussia (1982), Spain (1992-93), Switzerland (1993-94), the UK (1995). Doctor Habil (2000, power engineering and heat engineering) Member of International Association of Energy Economics. Research interests: optimisation of energy consumption of building, life cycle analysis.

Artur ROGOŽA. PhD student. Assistant. Dept of Heating and Ventilation. Vilnius Gediminas Technical University (VGTU), Sauletekio al. 11, LT-2040 Vilnius, Lithuania. E-mail: artur@ap.vtu.lt

MSc (heat engineering, 1999). PhD student (VGTU, 1999). Co-author of 1 scientific publication. Research interests: optimisation of energy in district heating systems, life cycle analysis. 